Barker, G.M. 1989. Grass host preferences of Listronotus bonariensis (Coleoptera: Curculionidae). Journal of Economic Entomology 82: 1807-1816.

Goldson, S.L. 1982. An examination of the relationship between Argentine stem weevil (Listronotu bonariensis) and several of its host grasses. New Zealand Journal of Agricultural Research 25: 395-404.

Goldson, S.L. 1981: Reproductive diapause in the Argentine stem weevil (Listronotus bonariensis (Kuschel) (Coleoptera: Curculionidae) in New Zealand. Bulletin of Entomological Research 71: 275-287.

Goldson, S.L.; Proffitt, J.R.; Baird, D.B. 1998. The bionomics of Listronotus bonariensis (Coleoptera: Curculionidae) in Canterbury, New Zealand. Bulletin of Entomological Research 88: 415-423.

Goldson, S.L.; Tomasetto, F.; Popay, A.J. 2014 Biological control against invasive species in simplified ecosystems: its triumphs and emerging simplifed ecose threats. Current Opinion in Insect Science 5: 50-56.
Jensen, J.G.; Popay, A.J.; Tapper, B.A. 2009. Argentine Jensen, J.G.; Popay, A.J.; Tapper, B.A. 2009. Argentine
stem weevil adults are affected by meadow fescue endophyte and its loline alkaloids. New Zealand Plant Protection 62: 12-18

Mortimer,P.H.; Di Menna, M.E. 1983.Lolium endophyte aetiology and the discovery of weevil resistance of ryegrass pastures infected with Lolium endophyte. Proceedings of the New Zealand Grassland Association 44: 240-243.

Popay, A.J.; Wyatt, R.T. 1995. Resistance to Argentine stem weevil in perennial ryegrass infected with endophytes producing differen alkaloids. Proceedings of the 48th New Zealand Plant Protection Conference: 229-236.

Popay, A.J.; Thom, E.R. 2009. Endophyte effects on major insect pests in Waikato dairy pasture. Proceedings of the New Zealand Grassland Association 71: 121-126.

Popay, A.J.; Hume, D.E.; Mainland, R.A.; Saunders, C.J. 1995. Field resistance to Argentine stem weevil (Listronotus bonariensis) in different ryegras cultivars infected with an endophyte deficient in lolitrem B. New Zealand Journal of Agricultural Research 38: 519-528.

Popay, A.J.; Hume, D.E.; Baltus, J.G.; Latch, G.C.M.; Tapper, B.A.; Lyons, T.B.; Cooper, B.M.; Pennell, C.G.; Eerens J.P.J.; Marshall, S.L. 1999. Field performance of perennial ryegrass (Lolium perenne) infected with toxin-free fungal endophytes (Neotyphodium spp.). Grassland Research and Practice Series 7: 113-122.
Popay,A.J.; Hume, D.E.; Davis, K.L.; Tapper, B.A. 2003. Interactions between endophyte (Neotyphodium spp.) and ploidy in hybrid and perennial ryegrass cultivars and their effects on Argentine stem weevil (Listronotus bonariensis). New Zealand Journal of Agricultural Research 46: 311-319.

Popay, A.J.; Tapper, B.A.; Podmore, C. 2009. Endophyte-infected meadow fescue and loline alkaloids affect Argentine stem weevil larvae. New Zealand Plant Protection 62: 19-27.

Popay, A.J.; McNeill, M.R.; Goldson, S.L.; Ferguson, C.M. 2011. The current status of Argentine stem weevil (Listronotus bonariensis) as a pest in the North Island of New Zealand. New Zealand Plant Protection 64: 55-62

Prestidge, R.A. 1991. Susceptibility of Italian ryegrasses (Lolium multiflorum Lam.) to Argentine stem weevil (Listronotus bonariensis (Kuschel)) feeding and oviposition. New Zealand Journal of Agricultural Research 34: 119-125.

Prestidge, R.A.; Pottinger, R.P.; Barker, G.M. 1982. An association of Lolium endophyte with ryegrass resistance to Argentine stem weevil. Proceedings of the 35th New Zealand Weed and Pest Control Conference: 119-122.

Sciencebuddies. Retrieved on 9-06-2015 from http:// www.sciencebuddies.org/science-fair-projects/ project_ideas/Soc_participants.shtml

Simpson, W.R.; Faville, M.J.; Moraga, R.A.; Williams, W.M. McManus, M.T.; Johnson, R.D. 2014 Epichloe fungal endophytes and the formation of synthetic symbioses in Hordeeae (=Triticeae) grasses. Journal of Systematics and Evolution 52: 794-806.

Thom, E.R.; Popay, A.J.; Waugh, C.D.; Minneé, E.M.K. 2014. Impact of novel endophytes in perennial ryegrass on herbage production and insect pests from pastures under diry cow grazing in nom pastures un daly cow grazing in northern New

Zealand. Grass and Forage Science 69. 191-204.

hom, E.R.; Popay, A.J.; Hume, D.E.; Fletcher, L.R. 2012. Evaluating the performance of endophytes in farm systems to improve farmer outcomes - a review. Crop and Pasture Science 63: 927-943.

Tomasetto, F.; Tylianakis, J.M.; Reale, M.; Wratten, S.; Goldson, S.L. 2017. Intensified agriculture favors evolved resistance to biological control. Proceedings of the National Academy of Sciences 114: 3885-3890. hatnan, C.P. 1959: Damnge to pastures by wheatstem weevil. New Zealand Journal of Agriculture $551-552$.

\title{
Lime application can help protect pastures against black beetle
}

P.J. GERARD and D.J. WILSON

AgResearch Ruakura, Private Bag 3123, Hamilton 3240, New Zealand

pip.gerard@agresearch.co.nz

\section{Abstract}

Black beetle attacks pasture grasses in the northern and coastal North beetle has more prevalent. On-farm investigations into prevention of damaging populations suggested that black beetle density was inversely related to soil $\mathrm{pH}$. Two replicated block experiments, the first in 2013-2015 on two farms, and the second on four farms in 2015-2017 investigated the effects of late spring agricultural lime applications at the rate of 5 tonne/ha on summer black beetle populations. The results showed that lime can help suppress black beetle populations. Importantly, the effect of lime persisted into the second year in Trial 2, preventing larval populations reaching damaging levels of over $40 / \mathrm{m}^{2}$. This adds to the already well-known benefits of lime in improving soil health and pasture quality, vigour and persistence.

Keywords: agricultural lime, soil $\mathrm{pH}$

\section{Introduction}

Black beetle (Heteronychus arator (Fabricius) Coleoptera: Scarabaeidae) is a subtropical pest of pasture grasses in New Zealand districts with a mean annual surface air temperature of $12.8^{\circ} \mathrm{C}$ and above (Watson 1979). This includes Northland, Waikato, Bay of Plenty and coastal areas of the northern North Island from Whanganui in the west, around to Cape Kidnappers in the east (Bell et al. 2011). With the warmest (2016) and $3^{\text {rd }}$ warmest (2013) years in the last decade and above average seasonal temperatures common (NIWA 2017), damage has become more prevalent in traditionally sporadically infested areas, and the beetle has extended its range inland and southward with sports field turf damage reported in Foxton in 2014 (B. Hannan pers. comm.).

Important factors contributing to damaging black beetle populations are above average temperatures, free-drining soils and avalibility of favoulable fod resources. Widespread black beetle outbreaks are associated with strong La Niña weather patterns which, on average, bring warmer than normal temperatures over the North Island in spring and autumn (Gerard et al. 2013). High spring temperatures (growing degree days above $15^{\circ} \mathrm{C}$, King et al. $1981 \mathrm{~b}$ ) encourage population increase while wet conditions are unfavourable for early instar larval survival (King et al. 1981c). $\mathrm{C}_{4}$ grasses, as well as ryegrasses (Lolium spp.) without we (King in turing and oviposition are reduced by ryegrasses containing standard, AR37, NEA2 or Endo 5 endophytes (Ball $e$ al. 1997; Popay \& Baltus 2001; Bell et al. 2011).

A major outbreak of black beetle occurred in Waikato and Bay of Plenty from 2007 to 2010, and many farmers experienced widespread failure of perennial pastures (Bell et al. 2011). While climate and black beetle were not the only factors, losses were reported of about . Since then, the widespread use of black beetle-active yegrass endophytes, in particular AR37, has enabled pastures to persist even under drought condition (Thom et al. 2014). However, with ongoing higher annual temperatures, pastures on peat or light soils still experience damage. Consequently there remains a high demand for additional practical tools to help combat this pest in established pastures.

In the course of analysing data gathered from 12 paddocks across five Waikato farms during a black beetle/pasture persistence study, it was found that black beetle density was inversely related to soil $\mathrm{pH}$ (Gerard $e t$ al. 2013). This paper reports on field studies undertaken to investigate if the application of agricultural lime can help reduce black beetle populations.

\section{Methods}

\section{Trial 1: 2013-2015}

The trial was a randomised block design consisting of four paddocks on Waikato dairy farms, two on a farm with peat soils (Taupiri 1 and 2, 37037'03.8”s $\left.175^{\circ} 17^{\prime} 30.9^{\prime \prime} \mathrm{E}\right)$ and two on a farm with ash soils (Waihou 1 and 2, 37 $\left.32^{\circ} 01.5^{\prime \prime} \mathrm{S} 175^{\circ} 38^{\prime} 50.0^{\prime \prime} \mathrm{E}\right)$. Each paddock (block) was divided into eight plots and AgLime supplied by McDonalds Lime (now Graymont) was applied at the rate of 5 tonne/ha to four randomly selected plots in each paddock on 4 November 2013 , by the commercial operator. Wealleans, using a purpose built $4 \times 4$ ground-spreading vehicle. The timing of the lime application was during the black beetle oviposition period.

Black beetle populations were sampled by taking five $20 \times 20 \mathrm{~cm}$ spade squares of turf to a depth of $15 \mathrm{~cm}$ and hand sorting in the field. This was done in December (a month after lime application) when the black beetle 
population consists of adults that have survived the winter, eggs and early instar larvae. The sampling was repeated in late January 2014 when 3rd instar larvae are prevalent and causing pasture damage

Soil $\mathrm{pH}$ was assessed by taking five $7.5 \times 2.5 \mathrm{~cm}$ core from each plot and pooling control and lime-treate samples from each paddock in April 2014. The samples were submitted to Hill Laboratories for analysis.

Lime was reapplied to the same plots as in 2013 in early November 2014 and the plots sampled for black beetle in December and January 2015.

\section{Trial 2: 2015-2017}

This trial was carried out on four Waikato farms (Table 1). At each site two paddocks (blocks A and B) were each split into four quarters (plots) and 5 tonne/ha of Aglime was applied to two randomly selected plots paddock using the same supplier and ground-spreading company as above. The first application was on 6 November

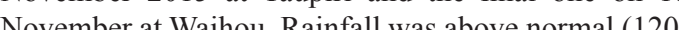
$149 \%$ ) and anper der. during November but hotter and drier than average over summer and and autumn (NIWA 2017). The large plots were used to lessen the amount of drift onto control plots which was perceived to be an issue in the previous trial. While the desired soil $\mathrm{pH}$ differences had been achieved below ground, there was visual evidence of lime particles on the control plot pasture during the black beetle oviposition period when adults were active above ground. Fence posts were tagged to show plo boundaries and "No lime" signs put on the paddock gate posts to prevent accidental additional applications by contractors.

Black beetle populations (and other large soil invertebrates) were sampled as in Trial 1 in midDecember 2015 and late-February 2016 by taking ten $20 \times 20 \mathrm{~cm}$ spade squares $\times 15 \mathrm{~cm}$ deep/plot. Plots were sampled a year later, in mid-December 2016 and February 2017. The majority of the population in the February samples were third instar larvae, but also $2^{\text {n }}$ instar larvae, pupae and new adults were present.

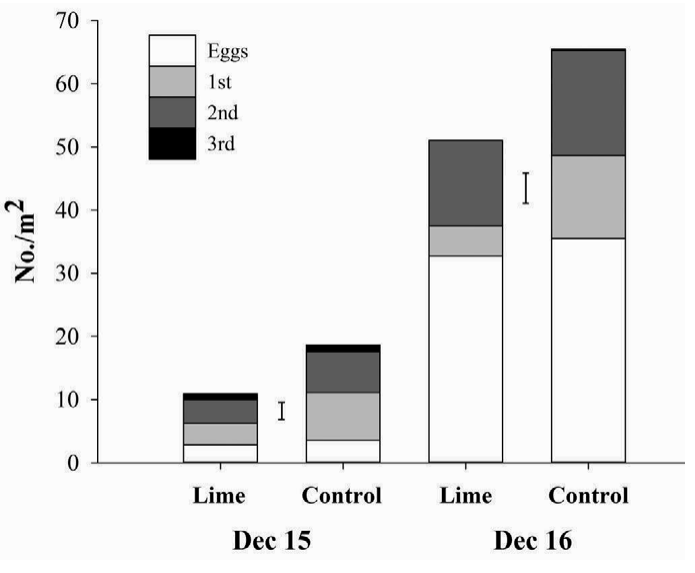

Figure 1 Comparison of the abundance of black beetle eggs and larvae in each instar in lime and control plots In 14-18 December 2015 and 5-7 December 2016. instar larvae in each year.

Ten $7.5 \times 2.5 \mathrm{~cm}$ deep soil samples/plot were taken in mid-March, the lime and control samples, pooled for each paddock, and the samples submitted to Hill Laboratories for analysis of soil nutrient levels, $\mathrm{pH}$ and soil organic matter. In October 2016, five $20 \times 20 \mathrm{~cm}$ spade squares $\times 10 \mathrm{~cm}$ deep were taken from every plot, sieved, and the $\mathrm{pH}$ of the pooled soil from each plot was assessed by mixing 15 of a of distilled water and reading the $\mathrm{pH}$ with a calibrated $\mathrm{pH}$ meter.

\section{Statistical analyses}

Black beetle data from both trials were analysed by ANOVA, as were soil analytical data in Trial 2. In Trial 1 , a paired sample t-test was performed on $\mathrm{pH}$ data from samples collected from treated and untreated plots within the same paddocks.

\section{Results}

The November 2013 lime applications raised soil pH to an average of 6.0 across the treated plots, producing a significant contrast to the control plots averaging at $\mathrm{pH} 5.7(\mathrm{P}<0.01)$ in late April 2014.

Table 1 Lime trial 2 experimental site coordinates, farm type and organic mate Figure 1 summarises

\begin{tabular}{lcccc}
\hline Locality & \multicolumn{1}{c}{ Coordinates } & Type & \multicolumn{2}{c}{ Soil organic matter \% } \\
\cline { 4 - 5 } & & & Paddock A & Paddock B \\
\hline Taupiri & $37^{\circ} 37^{\prime} 08.3^{\prime \prime} \mathrm{S} 175^{\circ} 17^{\prime} 22.7^{\prime \prime} \mathrm{E}$ & Dairy & 49 & 39 \\
Waihou & $37^{\circ} 32^{\prime} 05.1^{\prime \prime} \mathrm{S} 175^{\circ} 39^{\prime} 39.0^{\prime \prime} \mathrm{E}$ & Dairy & 25 & 20 \\
Gordonton & $37^{\circ} 40^{\prime} 43.4^{\prime \prime} \mathrm{S} 175^{\circ} 18^{\prime} 09.5^{\prime \prime} \mathrm{E}$ & Dairy & 26 & 21 \\
Ruakura & $37^{\circ} 46^{\prime} 03.3^{\prime \prime} \mathrm{S} 175^{\circ} 19^{\prime} 15.8^{\prime \prime} \mathrm{E}$ & Dry stock & 22 & 41 \\
\hline
\end{tabular}
black be date for Decepulation data for Decenber and mid-late January (when $3^{\text {rd }}$ instar larvae are causing pasture damage) for the two summers following lime application in

$1.72 \times$ total carbo
December sampling appear lower than at the later sampling because oviposition is still occurring and even skilled researchers can miss some newly laid eggs and newly hatched larvae while hand sorting in the field. In December 2013, a month after lime application, there was an overall $40 \%$ reduction in black beetle abundance in the limed plots compared to the control plots $(\mathrm{P}=0.022)$. The effects were most pronounced at Taupiri $(\mathrm{P}<0.001)$ but were not significant at Waihou where there was no respo in one padlock and $30 \%$ whe there was no respons reduction in larve in the oher. The $31 \%$ difference untreated plots in late January 2014 was not significant $(\mathrm{P}=0.087)$

A similar pattern was apparent in December 2014

at Taupiri with lime application having a positive effect in both paddocks $(\mathrm{P}=0.034)$. However, no other significant treatment effects were found that summer.

Trial 2

The November 2015 lime applications in Trial 2 raised soil $\mathrm{pH}$ from an average of 5.75 in the control plots to 5.93 in the lime plots $(\mathrm{SED}=0.022$, $\mathrm{P}<.001)$ by March 2016 with all paddocks showing similar responses except for Ruakura B which did not change at all. Levels appeared lower and further apart by October $2016 \quad(5.38$ versus 5.81 $2016 \quad(5.38$ versus 5.81, $\mathrm{SED}=0.043, \mathrm{P}<.001$ ) but
these later samples may not the directly comparable as the soil had been sieved fo laboratory experiments not reported in this paper. The other significant changes in soil chemisty following increase in $\mathrm{Ca}(22.7$ to 25.5 , $\mathrm{SED}=0.82, \quad \mathrm{P}=0.011)$ an decrease in organic matte (30.0 to $27.5, \mathrm{SED}=0.90$ $\mathrm{P}=0.036$ ).

Mean black beetle abundance in the control 2017. and lime treatments in each Trial 2 paddock at each ampling date are presented in Table 3 and the overall effect of the treatments on egg and larval instar abundance in December in Figure 1 .

In December 2015, one month after treatment, there was a significant overall $41 \%$ reduction in black beetle larval populations in the limed plots compare to control plots $(\mathrm{P}=0.038)$. However, by late February/ early March 2016 the treatment effect was not as strong (mean decrease $26 \%, \mathrm{P}=0.057$ ).

The following summer, larval populations in December 2016 were reduced across all sites by $47 \%$ $\mathrm{P}=0.017)$ in the lime plots compared to the contro plots, with the biggest response in first instar larvae (4.8

Table 2 Comparison of April 2015 soil pH and mean ( \pm standard error, SE) black beetle population abundance on lime and control plots in two paddocks ( 1 and 2) at Taupiri and Waihou sites on four sampling dates.

\begin{tabular}{lccccccc} 
Site & Block & Treatment & pH & Dec 13 & Jan 14 & Dec 14 & Jan 15 \\
\hline Taupiri & 1 & Control & 6.0 & $33 \pm 6$ & $33 \pm 17$ & $21 \pm 6$ & $19 \pm 4$ \\
& & Lime & 6.3 & $9 \pm 4$ & $20 \pm 6$ & $8 \pm 4$ & $19 \pm 5$ \\
& 2 & Control & 5.4 & $6 \pm 3$ & $11 \pm 4$ & $19 \pm 7$ & $35 \pm 12$ \\
& & Lime & 5.7 & $3 \pm 3$ & $15 \pm 7$ & $8 \pm 5$ & $20 \pm 8$ \\
Waihou & \multirow{1}{*}{1} & Control & 5.7 & $24 \pm 6$ & $25 \pm 7$ & $60 \pm 28$ & $45 \pm 10$ \\
& & Lime & 6.0 & $24 \pm 7$ & $24 \pm 7$ & $33 \pm 11$ & $56 \pm 14$ \\
& 2 & Control & 5.5 & $36 \pm 10$ & $39 \pm 12$ & $46 \pm 15$ & $25 \pm 6$ \\
& & Lime & 6.0 & $25 \pm 8$ & $16 \pm 6$ & $76 \pm 20$ & $24 \pm 6$ \\
\hline
\end{tabular}

Table 3 Comparison of March 2016 soil pH and mean ( \pm SE) black beetle population abundance on lime and control plots in two paddocks (A and B) at Taupiri, Waihou, abundance on lime and control plots in two paddocks (A and $B$ ) at Taupiri, Waihou,
Gordonton and Ruakura sites on four sampling dates December 2015- February

\begin{tabular}{lccccccc}
\hline Site & Block & Treatment & pH & Dec 15 & Feb 16 & Dec 16 & Feb 17 \\
\hline Taupiri & A & Control & 5.8 & $26 \pm 8$ & $48 \pm 7$ & $26 \pm 7$ & $40 \pm 7$ \\
& & Lime & 6.0 & $10 \pm 6$ & $26 \pm 5$ & $30 \pm 9$ & $34 \pm 5$ \\
& B & Control & 6.2 & $1 \pm 1$ & $28 \pm 8$ & $39 \pm 16$ & $59 \pm 9$ \\
& & Lime & 6.4 & $8 \pm 5$ & $24 \pm 6$ & $15 \pm 5$ & $59 \pm 15$ \\
Waihou & A & Control & 5.8 & $11 \pm 4$ & $21 \pm 6$ & $58 \pm 20$ & $76 \pm 12$ \\
& & Lime & 6.1 & $9 \pm 6$ & $16 \pm 6$ & $46 \pm 11$ & $48 \pm 10$ \\
& \multirow{2}{*}{ B } & Control & 6.0 & $25 \pm 9$ & $16 \pm 3$ & $53 \pm 11$ & $53 \pm 8$ \\
& & Lime & 6.2 & $8 \pm 4$ & $9 \pm 3$ & $39 \pm 13$ & $36 \pm 9$ \\
Gordonton & A & Control & 5.5 & $18 \pm 6$ & $39 \pm 7$ & $31 \pm 9$ & $104 \pm 18$ \\
& & Lime & 5.7 & $19 \pm 5$ & $29 \pm 7$ & $23 \pm 5$ & $51 \pm 9$ \\
& B & Control & 5.5 & $35 \pm 6$ & $35 \pm 7$ & $44 \pm 13$ & $74 \pm 13$ \\
& & Lime & 5.6 & $11 \pm 6$ & $28 \pm 5$ & $41 \pm 13$ & $50 \pm 12$ \\
Ruakura & A & Control & 5.6 & $13 \pm 5$ & $6 \pm 2$ & $11 \pm 8$ & \\
& & Lime & 5.8 & $5 \pm 3$ & $6 \pm 2$ & $10 \pm 6$ & \\
& \multirow{2}{*}{ B } & Control & 5.6 & $11 \pm 6$ & $24 \pm 4$ & $0 \pm 0$ & \\
& & Lime & 5.6 & $11 \pm 5$ & $25 \pm 4$ & $0 \pm 0$ & \\
\hline & & & & & & &
\end{tabular}


$\mathrm{m}^{2}$ versus $13.2 / \mathrm{m}^{2}$, respectively, $\left.\mathrm{SED}=3.2 \mathrm{P}=0.013\right)$. There was no effect on egg abundance $\left(35.5 / \mathrm{m}^{2}\right.$ versus $32.7 / \mathrm{m}^{2}$, respectively)

As no black beetle were found in Ruakura paddock B low numbers in paddock A (around $5 / \mathrm{m}^{2}$ ) in December 2016, neither of these dry stock paddocks were sampled in February 2017. Over the six remaining dairy farm paddocks the lime treated plots had $32 \%$ fewer black beetle in the lime plots compared to the control plots $\left(46.3 / \mathrm{m}^{2}\right.$ versus $\left.67.5 / \mathrm{m}^{2}, \mathrm{SED}=19.2, \mathrm{P}=0.007\right)$. Black beetle numbers on these farms were markedly high in February 2017 , averaging $57 / \mathrm{m}^{2}$ compared to $26 / \mathrm{m}^{2}$ in the previous year $(\mathrm{SED}=21.9, \mathrm{P}<0.001)$.

Regression analysis showed February 2017 black beetle abundance on the dairy farms decreased with increasing soil $\mathrm{pH}\left(\mathrm{y}=-32 \mathrm{x}+236, \mathrm{R}^{2}=0.27, \mathrm{P}=0.010\right)$

Application of lime did not appear to impact on the abundance of other soil macro-invertebrates. Earthworms were most abundant in December 2016 averaging $120 / \mathrm{m}^{2}$ on the control plots and $113 / \mathrm{m}^{2}$ on lime plots $(\mathrm{SED}=17.8, \mathrm{P}=0.70)$, neither were there any differences in wireworm Conoderus exsul (Sharp) larval numbers $\left(12.3\right.$ and $15.8 / \mathrm{m}^{2}$, respectively ( $\mathrm{SED}=2.8, \mathrm{P}=0.22$ )

\section{Discussion}

The results from these two trials, combined with the previous finding that greater populations of black beetle are associated with lower soil pH (Gerard et al. 2013), show that the application of lime can help supress black beetle. Importantly, the effect of the lime application persisted into the second year in Trial 2. As indicated by the regression analysis, soil $\mathrm{pH}$ only explain around $30 \%$ of the variation in black beetle abundance, so it is important to combine this new informatio with other known management tools for black beetle such as grasses containing black beetle-active fungal endophytes (Neotyphodium spp.) and the use of insecticide-treated seed when renovating pastures in black beetle-prone districts.

Late instar black beetle larvae are the most damagin stage, feeding on roots close to the surface. King et al. (1982) showed that a larval population of $43 / \mathrm{m}^{2}$ in ryegrass/white clover pasture resulted in $67 \%$ loss of ryegrass and a $30 \%$ increase in clover over summer and autumn in the first year on infestation. Generally, the reshold is considered to be between 40 and 60 larvacim the pasture is under. For example, during a wet summer Watson et al. (1980) observed some paddocks with ove 75 larvae $/ \mathrm{m}^{2}$ had only a brief period of pulling damage in late summer. In contrast, when ryegrass is stressed (e.g. hot, dry summers, intensive grazing or pressure from other pests), populations as low as $20 / \mathrm{m}^{2}$ could cause problems (Bell et al. 2011). Pasture production was not able to be assessed during this trial but given the high larval populations in summer 2017 following the warmest year on record in 2016 (NIWA 2017), the $32 \%$ reduction in larvae in the lime treatments compared to the control treatments is likely to have lessened the impact of black beetle damage on dry matter production in summer and early autumn, ryegrass persistence and weed invasion.

While Oemeeod (1889) reported that a South African farmer had success in controlling black beetle by applying lime, there have been few studies specifically investigating interactions between lime applications and soil-dwelling pests. Judas (2002) found that the density of click-beetle larvae (Elateridae) decreased in forest stands after liming. Similarly, increasing soil pH from 4.8 to 5.7 decreased Diaprepes abbreviatus root weevil larval populations feeding in citrus groves (Li et al. 2007). However, lime application and soil pH did not inpact on larval Popillia japonica (Vitum 1984; Vitum \& Morzuch 1989) in studies investigating anecdotal reports of efficacy on golf courses. Nor did lime have any impact on sugar cane whitegrub numbers in the Midlands area of South Africa (McArthur 2005). King (1985) found improving soil fertility of an acid soil through applications of lime and phosphate fertilisers increased larval populations of the scarab Phyllophaga vicina in maize in Costa Rica. Therefore published literature provides little assistance as to possible direct or indirect mechanisms of lime.

Liming appears to reduce black beetle early instar larval populations rather than eggs (Figure 1), suggesting the differences in abundance between treated and control plots are due to larval survival rather than adult oviposition. As the effect in Trial 2 was equally strong in the second year after application, it would appear the effect is not a transient phenomenon restricted to immediately after application. First restictor ten soil organic matter (King et al. 1981b) and like other scarabs (e.g. Pachnoda ephippiata, Egert et al. 2003), develop a complex microbial community in their mid- and hindguts to transform the ingested soil organic matter. It is known that the addition of lime has a strong effect on the soil microbial community structure, activity and biomass (Kennedy et al. 2004; Wakelin et al. 2009). It is possible that newly hatched larvae will be affected by these changes in several ways including which microbes colonise the neonatal gut and microbialinduced changes to organic matter quality.

The Ruakura dry stock paddocks contrasted greatly with the dairy paddocks, in particular the lack of soil $\mathrm{pH}$ response to the lime application in Ruakura B. This may be due to the particularly dense turf and thick thatch in this pasture and low summer and autumn rainfall following application (NIWA 20 which may have inhibited the movement of lime into the soil during the time of the study. Ruakura A had, comparatively, low black beetle abundance at both 2016 sampling dates and Ruakura B had no black beetle in December 2016. Both were old pastures ( $>20$ years) with lax management. While the original cultivars sown are unknown, it can be assumed from pasture age that they were perennial ryegrasses containing wildtype endophytes (Neotyphodium lolii Glenn, Bacon type end \& Hanlin), and other pest-resilient self-sown grasses. In contrast, while some of the dairy pastures were last cultivated several
decades ago, they had been intensively managed to maintain pasture quality and productivity (e.g. Taupiri B had been undersown in autumn with modern perennial ryegrass cultivars three times in the last 10 years, twice with Alto AR37 and most recently with Trojan NEA2). As AR37 and wild-type endophytes have similar effects in supressing oviposition and no detrimental effects on black beetle larval development (Bell et al. 2011), the population differences are likely to be driven by other factors such as invasion of favourable host grasses (e.g. C4 grasses and Poа апnиa) and below-ground interactions. Davidson et al. (1980) reviewed scarab responses that may contribute to observed population increases in improved pastures and found larval growth appears to be correlated with pasture species, root density, organic matter other than roots, soil moisture and microbial biomass.

In conclusion, while it must be emphasised that lime applications are not a 'cure' for black beetle, the results indicate that application of agricultural lime at 5 tonnes/ha can help mitigate black beetle damage and that the effect persists at least into the second year. This adds to the already well-known benefits of lime in improving soil health and pasture quality, vigour and persistence. We recommend farmers in black beetleprone regions optimise soil acidity to around $\mathrm{pH} 6$ to both help mitigate black beetle and boost pasture vigour to withstand the pest.

\section{ACKNOWLEDGEMENTS}

The authors thank Martin Henton, Stuart King, David MacDonald and AgResearch Farm manager Tim Hale, for use of the farms and the entire Waikato Black Beetle Action group for their enthusiasm and willingness to participate in black beetle research. We thank our colleagues and summer students who helped with the sampling of these trials, Moira Dexter for soil $\mathrm{pH}$ analyses and Catherine Cameron and Martin Upsdell for the data analyses. The work was supported by the Sustainable Farming Fund Projects SFF 11/035 and 408125, with co-funding from DairyNZ (OF1406 and BP1504), Ballance Agrinutrients, Graymont NZ and the C. Alma Baker Trust.

\section{REFERENCES}

Ball, O.J.P.; Miles, C.O.; Prestidge, R.A. 1997. Ergopeptine alkaloids and Neotyphodium loliimediated resistance in perennial ryegrass against adult Heteronychus arator (Coleoptera: Scarabaeidae). Journal of Economic Entomology 90: 1382-1391.

Ball, O.J.P.; Prestidge, R.A. 1992. The effect of the endophytic fungus Acremonium lolii on adult black 20etle (Heteronychus arator) feeding. pp. 201-204. Protection Conference. Bell, N.L.; Townsend, R.J.; Popay, A.J.; Mercer, C.F.; Jackson, T.A. 2011. Black beetle: lessons from the past and options for the future. Grassland Research and Practice Series 15: 119-124.

Blank, R.H.; Olson, M.H. 1988. Effect of black beetle, in association with nitrogen and summer spelling, on pasture production on sandy soils. New Zealand Journal of Agricultural Research 31: 445-453.

Davidson, R.L.; Hilditch, J.A.; Wiseman, J.R Wolfe, V.J. 1980. Growth, fecundity, and mortality responses of Scarabaeidae (Coleoptera) contributing to population increases in improved pastures. pp. 66-70. In: Proceedings of the 2nd Australasian Conference on Grassland Invertebrate Ecology.

Egert, M.; Wagner, B.; Lemke, T.; Brune, A.; Friedrich, M.W. 2003. Microbial community structure in midgut and hindgut of the humus-feeding larva of Pachnoda ephippiata (Coleoptera: Scarabaeidae). Applied and Environmental Microbiology 69: 6659-6668.

Gerard, P.J.; Bell, N.L.; Eden, T.M.; King, W.M.; Mapp, N.R.; Pirie, M.R.; Rennie, G.M. 2013 Influence of pasture renewal, soil factors and climate on black beetle abundance in Waikato and Bay of Plenty. Proceedings of the New Zealand Grassland Association 75: 235-240.

Judas, M. 2002. Effects of amelioration liming on soil macrofauna groups. Forstarchiv 73: 83-91.

Kennedy, N.; Brodie, E.; Connolly, J.; Clipson, N. 2004. Impact of lime, nitrogen and plant species on bacterial community structure in grasslan microcosms. Environmental Microbiology 6: 10701080

King,A.B.S. 1985. Factors affecting infestation by larvae of Phyllophaga spp. (Coleoptera: Scarabaeidae) in Costa Rica. Bulletin of Entomological Research 75: 417-427.

King, P.D.; Meekings, J.S.; Mercer, C.F. 1982. Effects of whitefringed weevil (Graphognathus leucoloma) and black beetle (Heteronychus arator) populations on pasture species. New Zealand Journal of Agricultural Research 25: 405-414

King, P.D.; Mercer, C.F.; Meekings, J.S. 1981a. Ecology of black beetle Heteronychus arator. Influence of plant species on larval consumption, utilization and 
growth. Entomologia Experimentalis et Applicata

King, P.D.; Mercer, C.F.; Meekings, J.S. 1981b. Ecology of black beetle, Heteronychus arator (Coleoptera: Scarabaeidae) - influence of temperature on feeding, growth, and survival of the larvae. New Zealand Journal of Zoology 8: 113-117.

King, P.D.; Mercer, C.F.; Meekings, J.S. 1981c. Ecology of black beetle, Heteronychus arator (Coleoptera ( Scarabaeida) 24: 87-97.

Li, H.; McCoy, C.W.; Syvertsen, J.P. 2007. Controlling factors of environmental flooding, soil $\mathrm{pH}$ and Diaprepes abbreviatus (L.) root weevil feeding in citrus: larval survival and larval growth. Applied Soil Ecology 35: 553-565.

McArthur, D.G. 2005. The effect of liming on whitegrub numbers in the Midlands area of the South African sugar industry. pp. 287-289. In: Proceeding of the 78th Annual Congress of South African Sugar of the 78th Annual Congress
Technologists' Association.

Technologists' Association.
NIWA 2017. NIWA National Climate Centre Climate

NIWA 2017. NIWA National Climate Centre Climate
Summaries. Accessed 20 July 2017 www.niwa. co.nz/climate/summaries

Oemeeod, E.A. 1889. Notes and descriptions injurious farm \& fruit insects of South Africa. Simpkin, Marshall \& Co., London, England.

Popay, A.J.; Baltus, J.G. 2001. Black beetle damage to perennial ryegrass infected with AR1 endophyte.
Proceedings of the New Zealand Grassland Association 63: 267-271.

Reynolds, W.N. 2013. Addressing on-farm management to enhance pasture productivity and persistence. Proceedings of the New Zealand Grassland Association 75: 241-244.

Thom, E.R.; Popay, A.J.; Waugh, C.D.; Minneé, E.M.K. 2014. Impact of novel endophytes in perennial ryegrass on herbage production and insect pests from pastures under pestures Grass and Forage Science 69: 191-204.

Zealad. Grass and Forage Science 69: 191-204.

ittum, P.J. 1984. Effect of lime applications on Japanese beetle (Coleoptera: Scarabaeidae) grub populations in Massachusetts soils. Journal of Economic Entomology 77: 687-690.

Vittum, P.J.; Morzuch, B.J. 1989. Effect of soil pH on Japanese beetle (Coleoptera: Scarabaeidae) oviposition in potted turfgrass. Journal of Economic Entomology 83: 2036-2039.

Wakelin, S.A.; Gregg, A.L.; Simpson, R.J.; Li, G.D.; Riley, I.T.; McKay, A.C. 2009. Pasture management clearly affects soil microbial community structure and N-cycling bacteria. Pedobiologia 52: 237-251.

Watson, R.N. 1979. Dispersal and distribution of Heteronychus arator in New Zealand (Coleoptera: Scarabaeidae). pp. 149-152. In: Proceedings of the 2nd Australasian Conference on Grassland Invertebrate Ecology.

\section{Dry matter yield and the prevalence of barley yellow dwarf and ryegrass mosaic viruses in old and young perennial ryegrass}

M.B. FARQUHAR ${ }^{1}$, C.S. WINEFIELD ${ }^{1}$ and C.C. EADY ${ }^{2}$ Lincoln University, Wine and Food Molecular Biosciences, Ellesmere Junction Rd, Lincoln 7647, New Zealand Agriseeds Ltd, 2547 Old West Coast Road, RD1, Christchurch, 7671, New Zealand ceady@agriseeds.co.nz

\section{Abstract}

Modern pasture management of perennial ryegrass results in reduced reseeding and increased reliance on asexual tiller multiplication. This may exacerbate viral impact by providing longer-living hosts to exploit, thus the effect of ryegrass age on sward performance and viral load was investigated. Genetically similar 10 year old field plants and 10 year old seed were used to produce 'mini-swards' of 'old' (tiller derived) and 'young' (seed derived) ryegrass lines. Dry matter yield and viral load (ryegrass mosaic, and barley yellow dwarf) were assessed over 10 months. For all lines the old mini-swards produced less biomass (4-29\%) and viral load was significantly greater at most time points. Cause and effect between viral load and yield were not proven as other factors such as genetic drift, epigenetics, or other latent pests or diseases could not be ruled out.

Keywords: Lolium perenne, barley yellow dwarf virus, ryegrass mosaic virus

\section{Introduction}

At the core of the livestock industry in New Zealand is pasture (Lee et al. 2012), the productivity and profitability of which is inextricably linked to its quality and performance (Minneé et al. 2010). In New Zealand, perennial ryegrass is the most commonly used pasture grass species (Lee et al. 2012; Stewart et al. 2014). Several viruses e.g. barley yellow dwarf virus (BYDV) and ryegrass mosaic virus (RGMV) can infect ryegrass and cause economic loss (Wilkins \& Catherall 1977; Latch 1980; Coutts \& Jones 2002), with RGMV infection rates of up to $60 \%$ (Webster et al. 1996) and yield losses of up to $50 \%$ in experimental inoculated swards of Italian ryegrass (Wilkins \& Hide 1976; Eagling et al. 1992). With New Zealand dairy farms producing $\sim 14$ t DM/ha/year (http://www.siddc.org.nz/sthld-demofarm/farm-walk-notes/pasture-growth/) it follows that this equates to a potential worst case loss of $\sim 4.2 \mathrm{tDM} /$ ha/year or between $\sim \$ 627$ to $\$ 960 / \mathrm{ha}$, according to the Forage Value Index (FVI,www.dairynz.co.nz) seasonal values (2016). In addition, multiple viral infections in ryegrass may act synergistically (Eagling et al. 1992; Guy 2014) as documented in other monocotyledons
(Carfrune et al. 2006). The massive shift to dairying and rigation in the South Island, and making silage instead of hay reduces natural reseeding, potentially requiring plants (tiller derived clones) to live longer and so giving viruses a greater opportunity to multiply and increase their burden on the plant. While reports on spread and incidence of viruses within individual plants in a sward are common (e.g. Webster et al.1996) methods to measure viral load within a sward per se and the impact f this, viru loen we hat the farmer is interested in; a new look at the effect of viral load in the sward on pasture performance is overdue. The hypothesis for this research is that viral load (not percentage of plants infected) within a sward is increased over time and reduces ryegrass yield and persistence.

\section{Methods}

\section{Plant material}

Five lines from part of a 10-year-old breeder's 'without endophyte' persistency trial were chosen in October 2014 from the New Zealand Agriseeds Ltd. breeding station at Courtenay, near Christchurch. These were diploid perennial ryegrasses coded Lp258, Lp256, R164, R141 and a tetraploid line called 'Bealey'. Twenty four 'mushroom-type fairy ring' ryegrass clumps (i.e the centre had died out and the grass plant ad spread by tillers growing outwards in a padial d, dug up and 60 washe 作 ransplanted into compost in germination trays ( 37 x 23 $\mathrm{cm}$ ) creating 'old swards'. In parallel, stored seed from the original seed batches used for the above, were sown to create equivalent density 'young swards'. Trays of both swards were kept outside at Courtney for 2 months before transplanting in May 2015 (two trays/sward) forming spaced mini-swards surrounded by turf grass. Swards were arranged in 5 by 6 rows with each line and treatment (old or young) randomised and represented in triplicate. Swards were left for 1 month to establish (Figures 1a, 1b).

Sampling protocol

To obtain samples for yield analysis, a reel mower with the blade at the same height for each sward $(\sim 3 \mathrm{~cm})$ 